\title{
Clarifying Ethical Constituents of God-Believing Employees to Mitigate the Outcomes of Rumors and Organizational Rumor Management
}

\author{
Hossein Khanifar, Ph.D. \\ Associate Professor, Faculty of Management. University of Tehran, Qom College \\ E.mail: khanifar@ut.ac.ir
}

Gholamreza Jandaghi, Ph.D.

Professor, Faculty of Management, University of Tehran, Qom College

E.mail: jandaghi@ut.ac.ir

Hamed Bordbar

MA Student in Pubic Management, University of Tehran, Qom College

E.mail: ha_bordbar@yahoo.com

Mahmoud Jangholi

MA student in Pubic Management, University of Tehran

E.mail: Mahmoudjangholi@yahoo.com

Accepted: December 16, $2011 \quad$ Published: January 30, 2012

Doi:10.5296/ijhrs.v2i1.1166 URL: http://dx.doi.org/10.5296/ijhrs.v2i1.1166

\begin{abstract}
By declining human spiritual belongings, the lack of ethics is considered as a major calamity of modern age. Disrespecting ethical codes and constituents in organizations and societies has caused that some ethical abnormal to be highlighted and involve the mind of managers and relevant authorities. Human get away of God believing and ethics - orientation as well as the
\end{abstract}


lack of a clear and precise definition of ethical prism in organizations have caused unethical rumor behavior. Rumor is an unethical behavior disseminated among people in order to be believed. It is disseminated from one person to another verbally without any document. It causes that organizational managers and officials emphasize on human God-believing nature to mitigate the rumor negative outcomes and rumor management. While defining the rumor, present paper addresses to etiology of rumor in local and international literature and finally points ethical constituents which mitigate organizational rumor and abnormal behaviors in the organization.

\section{Keywords}

Ethics, Professional Ethics, Rumors, Rumor Management, Value System

\section{Introduction}

"Ethics decline" is considered as one of the obvious outcomes of "modern age de-enchanting" (Shaygan, 2001: 17) which has caused resorting to schools such as hedonism, pragmatism and utilitarianism. Due to the attendance of uncommitted staff, organizations are facing with disadvantages of some workers. Such problems cause that ethics and ethical constituents considered by managers and relevant authorities. Therefore, ethic - orientation issue and defining organizational ethical prism are the most important concerns of all organizational managers. A problem which has accelerated this issue is the expansion organizational and social rumors. As an outcome of unofficial communications, rumors are common in organizations. Although some managers use rumors as news renewed as the result of collective discussions for their personal purposes, rumor is overall considered as an unethical organizational behavior disseminated in organization by employees with various aims, motivations and intents.

As an unethical organizational behavior, rumor is a special issue which believable for all people and is transferred from one person to another verbally without certain evidences. On this basis, to mitigate rumor outcomes, organizational managers can minimize false rumors by emphasizing ethical constituents and enhance positive outcomes and mitigate negative ones by rumor management.

\section{Problem description}

Addressing ethical issues by researchers is due to live in ethical crisis age (Stoner, 2000: 168; Zahedi, 2000: 231). An unethical behavior in organizations is converted to an important problem for all members of community. Ethical activities and behaviors in organizations is a concern of actors and researchers. People are worried on improper behavior of organizations and managers are concerned about employees' immoral action (Kincaid et al., 2008). On the other hand, ethical behaviors include good working habits, coordination with other people and needed skills to keep the job (Kegans, 2009). Overall, ethics is an inner commitment to a good life instead of commitment to implement a set of laws and rules (Buchholz and Rosenthal, 2005).

In all religions, a fundamental pillar for prosperity in human material and spiritual life is ethics and ethical privileges because that ethics enforces social interactions. Ethics has not 
only a social but also an organizational aspect and considering such constituent can promote organizational ethics and mitigate abnormal behaviors to the minimum level. A destructive and implausible behavior is rumor which is expanded in organizations due to various reasons. Michelson and Moulay define rumor as unofficial communications with other people without considering whether it is based on reality or not (Michelson and Moulay, 2000). On this basis, rumor is a preventive factor to achieve organizational goals which decreases organizational productivity. Organizations in an organization can be expanded in an organization rapidly like a destructive storm.

\section{Theoretical basics}

\section{Rumor description}

As an unethical behavior among organizational staff, rumor is defined as information transferred via a grapevine and its impact is determined by the anxiety level of rumor receiver (DiFonzo and Bordia, 2000; Rosnow and Fine, 1976). The accepted concept of rumor is that rumor is an interpersonal relationship without any evidence on its reality (Michelson and Moulay, 2000). In value system, "gossip" is equaled to rumor which means broadcasting artificial reports to create fright, scare and anxiety (Ragheb Isfahani, 1990: 189).

Knapp define rumor as: "believing an issue without official confirmation." Peterson and Gist (1951) studied rumor and public opinion and explained it as: "an unconfirmed definition or enunciation on events disseminated among people and cause public concern." Table 1 is a summary of rumor definitions.

Table 1: rumor definitions

\begin{tabular}{|l|l|l|}
\hline Author & Year & Definition \\
\hline Difonzo and Bordia & 2000 & Transferred information form unofficial networks \\
Rosnow and Fine & 1976 & Believing an issue without official confirmation \\
\hline Knapp & 1994 & $\begin{array}{l}\text { Unofficial relations with other people without } \\
\text { considering the facts }\end{array}$ \\
\hline Michelson and Moulay & 2000 & \\
\hline
\end{tabular}

\section{Affecting factors in rumor dissemination}

Rumor is like sea water: you feel thirstier when you drink more. Rumor creates fear and worry in society and people resort it due to lack of precise information and transfer it by word-of-mouth and sometimes, they added to its content. According to rumor definitions, it is determined that rumors have below characteristics:

- Rumor is news on a person or an event in the time being or in the past. Therefore, rumor is not a myth.

- The aim of the rumor is to be believed by other people. So, rumor is not a joke.

- Rumor is a collective work.

- Rumor is unconfirmed news.

- Rumor is about individuals, institutes, organizations and social entities to which people are sensitive.

- Rumor may be rooted in a lying or accusation (Bahrami, 2004: 72). 
A society needs a suitable ground as well as factors which accelerate rumor velocity in order that rumor phenomenon is shaped and expanded among audiences. These factors include:

\section{The intensity of emotional and affective tensions}

When inner emotions and feelings are highly intensified, mental connoisseurs and experts can disseminate the rumor in the society rapider and impact on more people. Critical situations like wars, riots, elections and so on are golden opportunities which pave more suitable ground to breed and disseminate rumors. In such circumstances - especially wars and crises - a considerable portion of people feel worry and affective tensions dominate people due to various reasons such as the possibility of increasing social and political insecurity, mental pressures and physical and financial threats.

The possibility of rumor dissemination would be highly mitigated if mental calmness and security are increased among people. It is more obvious among countries with religious believes. It a strong principle that by more belief and unity, more mental calmness will be dominated on public and the ground for rumor expansion will be eliminated (Shirazi, 2001).

\section{Information gap}

Another important factor in disseminating rumor is the society is its people information gap. Weakness and lack of information paves a suitable ground to accept any type of rumor. Since people demand enough information on concerning issues, they demand more information when they are more worried. Particularly, when there is a serious censor or when there is threatening news (due to public worry or anxiety). The impact of such information is further when it is more understandable for public (Shirazi, 2001).

\section{Deceit and deviational motivations}

Some rumors are simply devised and disseminated to deceive people's mentality and to mislead society from its natural route. Although such deceitful rumors do not apparently assure threat and hostility, they pursue spiteful aims on collective demands and interests. In addition to usual methods, publishing such rumors is also happened cleverly through newspapers and it is obvious that such method enjoys more power for mental destruction and mental deviation (Afruz, 1997).

A rumor in Islam attributed to the Prophet with the aim of deceitfulness was the issue of dividing booties after Hanin war. Hypocrites said that the Prophet does not behave equally in dividing the booties. In $58^{\text {th }}$ verse (Tobeh Sura) in Holy Koran, one can read: "there are some among them who find fault with you concerning the distribution of alms. If a share is given to them they are contented, but if they receive nothing then they are angry."

\section{Threatening motivations}

Sometimes, we are observing rumors that their only motivation is to threat other people. Some individuals try to publish rumor directly or indirectly to show their unreal abilities, to threat other people mentally, to weaken their morale and achieve their aims (Afruz, 1997). 


\section{Revealed and hidden hostility}

2011, Vol. 2, No. 1

Sometimes, the main motivation of some people, organizations or association to publish rumors is to show their revealed or hidden hostility against certain people, populations or countries. In other words, the hostile motivations and purposes can be the main factor for the prevalence of some spurious rumors in limited or broad levels. The problem of creating and disseminating rumors with hostile purposes and destructing individual or business personality of people, populations, entities and countries have a long history and have been blended with human social life. In fact, an important tool of enemy in destructing other party is to use the same technique (Afruz, 1997).

As an example, one can refer to some rumors attributed to the prophets that their aims were to disseminate rumors as well as the hostility of hypocrites and atheists. For example $60^{\text {th }}$ verse of Al-Araf Sura (The Heights) reads: "but the assembly of his nation said: 'we can see that you are in clear error." In this verse, the tribe of Noah disseminates the rumors on deceitfulness, and madness of Noah. Or $36^{\text {th }}$ verse of Al-Qasas Sura (The Story) reads: "and when Moses came to them with our clear signs, they said: 'this is nothing but forged sorcery. We have never heard of this among our fathers, the ancients". Likewise, $13^{\text {th }}$ verse of Naml Sura (The Ant) reads: "but when our signs came to them visibly, they said: 'this is plain sorcery".

In Islam, there some rumors about the Prophet Mohammad. Some rumors included that the Prophet was magician and poet, traitor and abnormal.

\section{Curiosity}

Many times, those people who have no intention to disseminate a rumor try to tell it for different individuals and to determine whether the project is true or false when they hear a rumor and when such rumor can impact their social and personal life. Unintentionally, such people disseminate the rumor only with the motivation to find the fact (Afruz, 1997).

\section{Making other people feel happy}

Many rumors are told to make other people to feel happy. In organizations, many rumors are disseminated only because that they are amazing and those who disseminate them have no attention to their contents. However, they are sure they impact on those people who gather them to hear the news (Bahrami, 2004: 83).

\section{Professional ethics}

Ethics has two different applications. Sometimes, ethics means temperament and habited behavior (Dehkhoda, 1993: 1296). Gupta and Suliman defined ethics by this questions "what should be done" (Evin, 2007: 107). Ethics is a set of spiritual objective processes that fully interfere in real self - growth and the process by which one can establish equilibrium in the functions of spiritual organic units (Allahi, 2000: 23).

Professional ethics is a set of do's and don'ts which should be respected by employees of an organization (society) to achieve committed working qualitative and quantitative conditions completely (Akbarian, 1991). The importance and emphasis of ethics in organizations is due to the fact that today organizations have expanded their structures and activities 
internationally and in various forms so that they are now converted into powerful tools for economic and social changes. Therefore, it is not surprising that the importance of ethics in organizations is increased in proportionate to their growth. According to Davies and Frederick (1985) ethics in business does not differs from ethics in society and professional ethics means the utilization of general ethical norms in behavior. They believe that differences in ethics in various aspects are seen in workplaces not ethical principles.

Respecting ethics in human life has a special status in Islam so that the most the greatest danger is known as ethical dissolution and breaking ethical borders. It is highly important and causes the human destruction. When someone exits his/her limitation and links other people especially an official one, the disaster will be multiplied if good ethics are not governing such human relations.

To the same reason, the best benchmark for any organization in Islam is its commitment to human ethics. It is not limited to Islam and all religions have considered ethics as the most fundamental principle. Overall, one can conclude that the growth and blossom of human talents are toward abstract perfection in work and are toward acting on the basis of professional ethics. Lack of ethics in job means the elimination of human/society blossom grounds to achieve abstract perfection.

There are scattered researches on professional ethics such a research by Posner and Schmidt which showed that professional ethics is not seen among lower managers compared to higher level ones (Posner and Schmidt, 1987; Andrisani, 1978; Anderson, 1995). There was no difference between poor and rich people in respecting professional ethics (Bullock, 1999; Cressey and Moore, 1983). Hegarty and Sims (1979) clarified that the organizations should devise some formal and informal policies to support ethical behaviors in order to increase respecting ethical principles (Hegarty and et al, 1979). Likewise, Cressey and Moore (1983) stated that the existence of ethical codes is not enough to enhance ethical behavior in organizations.

Professional ethics needs such belief that hardworking is the key of success and prosperity. Researchers have found that professional ethics accompanies with productivity, innovation, need to achieve success, job satisfaction, more income and consecutive attitudes and beliefs.

\section{Ethical constituents to decrease rumors}

Spirituality in job refers to those employees who are emotional in their job, acquire energy from their job, find meaning, feel that they have expressed themselves fully and communicate their colleagues. Heaton et al (2004) clarify that spirituality in job involves health, happiness, wisdom, success and fulfillment.

According to Fry (2005), spiritual values include honesty, forgiveness, hope, appreciation, humility, empathy and integrity. Mraques (2005) calls such values as honesty, forgiveness, appreciation, compatibility, kindness, creativity, respect, understanding, openness, confidence, acceptance and support. Similar to Marques, Reave (2005) introduces such values as significance, integrity, honesty, humility, respect, care, generosity, hearing, compatibility with other people and reactions (McGhee and Grant, 2008). By emphasizing on spirituality and enhancing it among organizational staff, managers can minimize spurious rumors. 


\section{Truthfulness}

It is in contrary to hypocrisy. It listens to inner voice, respects nobleness and involves in correct ethical behaviors despite of external pressures. Truthfulness in job does not mean to reveal all organizational facts and to publish all details; rather, it points out issues to which employees should be informed. One can read about the importance of truthfulness one can read in article 47 of Nahjolbalagheh: "the value of man depends to his effort and his truthfulness depends on his generosity." Article 67 reads: "a truthful person is on the way of deliverance while liar is the edge of perdition."

\section{Justice and fairness}

It is a fan of rightness. It has no bias in judgment and does not discriminate between people in terms of culture, social/economic class, race and tribe (Cadozier, 2002: 167). Respecting justice and fairness in treating with people can be seen as the most important ethical principle in religious teachings. In fact, no principle is emphasized like justice and fairness. Justice and fairness in behavior mean manager's equal treatment with all staff.

In letter 51 on justice and fairness, one can read: "treat people fairly." Also, one can read in letter 53: "respect fairness in your relation with the Divinity, people, relatives, and subordinated people who you like."

\section{Loyalty}

A loyal person obliges to its tasks, keeps others' secrets and is trusted by other people (Cadozier, 2007: 167). Loyalty to others causes that people do not resort rumor dissemination. Regarding the importance of loyalty, article 155 of Nahjolbalagheh reads: "respect your promises especially with loyal people." Article 41 reads: "loyalty is accompanied with honesty." Also, article 259 reads: "loyalty to traitors is a kind of treachery and treachery to traitors is loyalty in front of the Divinity."

\section{Patience and consent to the divine destiny}

Considering verses and narratives, it becomes clear that this ethical principle is praised for those people who do not achieve their desired result despite of their attempt in life. Since man cannot own all affecting factors on nature and world as well as other people's spirits, his expectations are not met sometimes and what happens is in contrary to his demand. Here, man should accept the reasons. So, in the hardest situation of war, Imam Hussein told his soldiers "consent to the divine destiny". Therefore, employees in an organization should be consent to the divine destiny against the most serious problems and they should be patient and know that "a patient person will not lose the victory even it is long." In advertising divinity message, the Prophets were faced with many problems by enemies but they were patient. In various verses, God orders fighters to be patient since each believer can overcome ten enemies by patience.

\section{Transparency}

One of the main principles and basic measures in global business ethics prism is transparency. It means to perform the affairs truthfully, sincerely, without any deceit and by keeping work 
processes and records. Usually, business depends on ethical pillars. The prerequisite of understanding and disseminating such target is transparency. It is repeatedly pointed out in Islam that "someone who deceits us is not one of us." "If buyers and sellers hide the facts and deceit, the blessing of their transaction will be removed (Ali and Al-Qwaihan, 2008: 11 -15). Transparency is a process by which information on current actions, decisions and statuses will be achievable, observable and understandable. Transparency is shaped by free information flow. Accountable organizations should be transparent and act on the basis of legal norms. According to Heritage lexicon, transparency is defined as: "the quality or state of transparency means the ability to light in a manner that all things and images are observable clearly. Transparency will be achieved when the content of provided information is observable for organizations."

\section{Employees' ingenuity and politico}

Employees should be fully aware of surrounding events and they should not be $\mathrm{n}$ naive and credulous. They should think about organizational rumors. Lack of thinking about organizational messages and data can lead that rumors are accepted and believed by staff.

On this basis, the expansion of rumor is the result of naivety of readers/listeners. When people do not study on the purposes of rumor makers and accept blindly everything they hear, they will be faced with irrevocable damages. In value system, it is highly emphasized that all news should be investigated and they should not be transferred to others when its correctness/incorrectness is not determined. in this regard, $6^{\text {th }}$ verse of Sura reads: "believers, if an evildoer brings you a piece of news, inquire first, in case you should unwittingly wrong others and then repent of what you have done".

Article 339 reads: "the strength of vote is for someone who has power and asset and uses his power and asset rightly." Article 181 reads: "the result of shortcoming is regret and the result of foresight is health."

\section{Favorable opinion and optimism}

Employees should have a favorable opinion and avoid pessimism in order to prevent excessive sensitivity to phenomena and events in their organizations. Article 248 reads: "when some has a favorable opinion on you, confirm his optimism." Also, article 360 reads: "it is not merit to be pessimism to what other people tell since you can perceive it positively."

\section{Self-Control}

When we address and being aware of ourselves, control becomes an inner factor. In our philosophical literature, such issues are seen. A seeker overcomes all external forces when he/she is aware of himself/herself and what protects and controls him/her is an inner factor (Soltani, 1999: 31). Regarding organizational rumor, a factor which leads into the shaping and disseminating incorrect news is tongue. Article 60 reads: "untreated tongue is like a rapacious which tears if you release it."

\section{Conclusion and Recommendations}

Organizational rumors are considered as an objective implication of immoral and abnormal 


\section{Macrothink

ethics of organizational staff in the third millennium. Although managers emphasize on such concepts as organizational commitment, spirituality and so on, illogical behaviors like rumor dissemination among employees are too common. To mitigate organizational rumors and to manage organizational rumors, one should make HR as God-believers, should enhance ethical constituents among them and should emphasize on such constituents to mitigate the negative outcomes of organizational rumor. Below, some recommendations are provided to mitigate organizational rumor and to manage the rumors:

1. Before rumor prevalence, some preventive initiatives should be taken. In fact, management should take necessary measures against such undesired phenomenon by its foresight.

2. Management should treat with rumor disseminators fairly by identifying rumor resources and aware them on this undesired phenomenon.

3. Management should be honest with its staff and people and tries to provide them with correct information so that rumor disseminators will not be able to produce rumors.

4. Management should take necessary measures to refuse organizational rumors. When no measure is taken, rumors are disseminated by word-of-mouth and they would have more destructive effects. 


\section{References:}

Stoner, James and et al (2000), Management, translated by Ali Parsaeian and et al, Tehran, Cultural Researches Office

Afruz, Gholam Ali (1991), rumor psychological basics

Akbarian, A. (1991), ethics in job, Tadbir Monthly, vol. 79

Bahrami, Mohammad (2004), rumor pathology in Koran

Dehkhoda, Ali Akbar (1993), Lexicon, vol. 1, University of Tehran

Ragheb Isfahani, Hussein (1990), Mofradat Alfaz Koran, Tehran

Zahedi, Shamsolsadat (2000), transnational and global Management: a comparative attitude, Tehran, SAMT.

Shaygan, Darius (2001), new incantation: forty-piece identity and mobile thinking, translated by Fatemeh Valini, Tehran: Farzan.

Shirazi, M. (2001), mental war and advertisements: concepts and functions,

Allahi, Bahran (1997), the basics of inner spirituality, translated by Melika Mabren and Farzad Yamini, Paris: Dury

Ali, Abbas J. Al-Owaihan, Abdullah (2008), Islamic work ethic: a critical review Cross Cultural Management: An International Journal Vol. 15 No. 1, 2008. Pp. 5-19.

Anderson, E. (1995), the Black Inner-City Grandmother: Transition of a Heroic Type? In American's Working Poor, edited by T.r. Swartz and K. Maas Weigert. Notro Dame, Indiana: University of Notre Dame Press. Pp. 9-43.

Andrisani P.J. (1978) a. Internal-External Attitudes, Personal Initiative, and Labor Market Experience. Pp. 101-134 in Work Attitudes and Labor Market Experience, edited by Paul J. Andrisani. New York: Praeger Publishers.

Buchholz, R. A., Rosenthal, S. B. (2005). The Spirit of Entrepreneurship and the Qualities of Moral decision Making: Toward a Unifying Framework, Journal of Business Ethics, Vol. 60, pp. 307-315.

Bullock, H. E. (1999), "Attribution for Poverty: A Comparison of Middle Class and Welfare Recipient Attitudes." Journal of Applied Social Psychology 29:2059-2082.

Cadozier, V, The moral profession: A study of moral development and professional ethics, Retrieved from proquest.com, 2002.

Cressey, D. R. and Moore, C. A. (1983), Managerial Values and Corporate Codes of Ethics, California Management Review 25: 53-77.

Cressey, D. R. and Moore, C. A. (1983), "Managerial Values and Corporate Codes of Ethics, "California Management Review 25: 53-77.

Davis, K. and Frederick, W. (1985), Business and Society,5 ed.

DiFonzo, N., \& Bordia, P. (2000). How top PR professionals handle hearsay: corporate rumors, their effects, and strategies to manage them. Public Relations Review, 173 - 190.

Evin, Hakan (2007). education management and ethics, www.e.sosder.Com

Hegarty, W. H. Sims, J. and Henry P. (1979), "Organizational Philosophy, Policies, and Objectives Related to Unethical Decision Behavior: A Laboratory Experiment, "Journal of Applied Psychology 64:331-338. 


\section{Al Macrothink}

Kegans, L. (2009). Occupational Work Ethic Differences: Implications for Organizational Diversity Initiatives in Health Care Organizations, Performance improvement quarterly , Vol. 22, N. 3. PP. 83-94.

Kincaid, C. S., Baloglu, S., Corsun, D. (2008). Modeling ethics: The impact of management actions on restaurant workers' ethical optimism, International Journal of hospitality management, Vol. 27, pp. 470-477.

Knapp, R. (1944). A psychology of rumor. Public Opinion Quarterly, 22- 37.

McGhee, P., Grant, P. (2008). Spirituality and Ethical behavior in the Workplace: Wishful Thinking or Authentic Reality, Electronic Journal of Business Ethics and Organization Studies, Vol. 13, No. 2, pp. 61-69.

Michelson, G., \& Moulay, S. (2000). Rumor and gossip in organizations:a conceptual study. Management decisions, 339- 46

Peterson, W., \& Gist, N. (1951). Rumor and public opinion. American Journal of Sociology, 159- 167.

Posner, B. Z. and Schmidt, W. H. (1987), "Ethics in American Companies: A Managerial Perspective, "Journal of Business Ethics ^:383-392.

Rosnow, R., \& Fine, G. A. (1976). Rumor and Gossip: The social psychology of hearsay. New York: Elsevier 